\title{
Separation of Palmitic Acid from over Used Oil for Production of Heterogeneous Organic Derivatives of Potential Biological Activities
}

\author{
Hanaa M. Soliman and Y. El- Shattory \\ Fats and Oils Dept., National Research Center, Dokki, Cairo, Egypt.
}

\begin{abstract}
DALMITIC acid was extracted from Over-used cooking oil where oil was filtered off, then it was hydrolyzed with distilled water in high pressure reactor at $250^{\circ} \mathrm{C}$ and $2 \mathrm{MPa}$ to produce glycerol and mixture of fatty acids. Fatty acids mixture was cooled at $7^{\circ} \mathrm{C}$ in order to precipitate all saturated fatty acids which were then filtered off, Palmitic acid was extracted from this mixture by means of supercritical $\mathrm{CO}_{2}$ extractor at $35.0 \mathrm{MPa}$ and $55^{\circ} \mathrm{C}$, followed by its methylation and confirmation by GC mass. Then it was used as precursor for production of a different heterocyclic compounds which were then tested for their antimicrobial activities. Thus the long-chain methyl palmitate was interacted with hydrazine hydrate to produce the corresponding acid hydrazide (2), and then it was treated with phenyl isothiocyanate, furnished the corresponding thiosemicarbazide 4 . The later was reacted with ethyl chloro(arylhydrazono) acetate $5 a-b$ in dimethylformamide, in the presence of triethylamine, afforded thiadiazole derivatives $7 \mathrm{a}-\mathrm{b}$. A solution of thiosemicarbazide 4 in ethanol was interacted with the $\alpha$-haloketones 9 in the presence of triethylamine, produced the parallel thiadiazine 12. The structure elucidation of all synthesized compounds is based on the elemental analysis and spectral data (IR, ${ }^{1} \mathrm{H}$ NMR, ${ }^{13} \mathrm{C}$ NMR and MS).
\end{abstract}

Keywords: Fatty acid hydrazides, Pathological conditions, Thiadiazoles, Haloketones, Thiosemicarbazide.

\section{Introduction}

Heterocycles is a highly serious division in organic chemistry as they play important roles in industrial and biological applications.

Industrially heterocycles are usually used in dyes, fluorescent agents, color change compounds, fire retardancy, photographic materials, recorders of information, electronics, food additives, cosmetics and perfumery ingredients [1].

Biologically they played a vital role in the living cells metabolism [2], medicinal chemistry and drug synthesis, also they possess various types of physiological activities. Triazole, thiadiazole and thiadiazine derivatives are well known to display anticonvulsant [2], anticancer activities [2], antiviral [3], anti-inflammatory [4], Painkiller [5-7], antihypertension [8], antibacterial [9], antimycobacterial [10-11], antifungal [12-14], antioxidant [15] and antidepressant [16].

Thus, this study is aimed to combine the beneficial biological effects of both of heterocycile and fatty acid in a single new compound by appending of a fatty acid to a heterocyclic compound. Thus the new synthesized compounds may possess various preferences over the origin heterocyclic one, where they could permeated through the lipoprotein cell membrane, on the other hand, it's possible to be stored in liver and skin as a lipid component in order to be used whenever they needed, more over the long chain fatty acid residue that surround the hetero nucleus may lower the toxicity and side effects of this new compounds [17].

Consequently, the over used cooking oil, was used in this study as a source of palmitic acid

Corresponding author: E-mail: chemist_hanaa@hotmail.com

DOI : 10.21608/ejchem.2017.889.1041

C2017 National Information and Documentation Center (NIDOC) 
which was then appended to triazole, thiadiazole and thiadiazine nucleus.

Appending of these heterocyclic compounds to stearic acid and oleic acid (those were obtained from pomace olive), had been previously prepared, and had proved a good biological activities $[17,18]$. This work is made as to explore whether the fatty acid chain length affect the biological activity of the heterocyclic compounds or not.

\section{Experiment}

\section{Material and methods}

The over used cooking oil was obtained from a local restaurant, hydrazine hydrate, phenylhydrazine, ethyl acetoacetate, and sulfuryl chloride were purchased from Aldrich Chemical Co. Bromine, and anhydrous aluminum chloride were purchased from Arcos Organics, Fisher Scientific Company (Belgium). Triethylamine, phenyl isothiocyanate, dimethylformamide (DMF), diethyl ether, benzene, dry dioxane, ethanol and methanol were purchased from British Drug House (BDH).

\section{Quality parameters of the oil}

Refractive index, free fatty acid, peroxide value and iodine value of the over used oil were determined following the analytical methods described by A. O. A. C. (2005) [19]. Insoluble oxidized fatty acids and insoluble polymer contents were carried out following the methods of Wu \& Nawar (1986) [20]. Polar and non-polar components were separated according to the method described by Waltking \& Wessels (1981)[21].

\section{Fatty acids composition}

The fatty acid composition of the over used oil was determined by GC-Capillary column according to the method reported by A.O.A.C. (2005) [19].

\section{Hydrolysis of the over used oil}

Palmitic acid was extracted from Over used oil according to the method described by Hanaa Soliman et al. [17]. Where The over used oil $(200 \mathrm{~g})$ was hydrolyzed using distilled water $(500 \mathrm{ml})$ and high pressure reactor at $250^{\circ} \mathrm{C}$ and $2 \mathrm{MPa}$ [22], then, the reaction left to cool to room temperature, where the reaction mixture was separated into two layers. The upper one contained the fatty acids while the lower one contained water, glycerol and unsaponifiable materials. The upper layer was then separated, dried over anhydrous sodium sulfate and filtered off. Formation of fatty acids was confirmed by $\mathrm{H}^{1} \mathrm{NMR}$ spectrum where signal at $\delta 10.2$ was observed which indicate the presence of carboxylic hydrogen. The lower layer which contains water, glycerol and unsaponifiable materials was transferred to rotator evaporator in order to remove water, the clear color less remainder (glycerol and unsaponifiable materials) was found to be $(16.2 \mathrm{~g})$, and thus oil can be considered to be completely hydrolyzed.

\section{Extraction of palmitic acid using supercritical CO2 extractor}

The separated fatty acids mixture (183.75 g) was cooled at $7{ }^{\circ} \mathrm{C}$ where all saturated fatty acids were solidified, filtered off and they were found to be $(87.76 \mathrm{~g})$. Palmitic acid was then extracted using supercritical $\mathrm{CO}_{2}$ extractor at pressure of $35.0 \mathrm{MPa}$ and temperature of $55^{\circ} \mathrm{C}$ [23]. The obtained palmitic acid (74.84 g) was confirmed by chemical analysis $(\mathrm{C}, 74.94 ; \mathrm{H}, 12.58 \%)$, melting point $\left(63^{\circ} \mathrm{C}\right)$ and GLC after its methylation, Then it was used as starting material for production of assortment of heterocyclic compounds.

\section{Organic preparations \\ Preparation of Chloro(arylhydrazono)ethyl acetate $(5 a-b)$}

To a solution of ethyl 2-chloro-3-oxobutanoate (1.64 $\mathrm{g}, 10 \mathrm{mmol}$ ) \{prepared by dropping a solution of sulfuryl chloride $(2.68 \mathrm{~g}, 20 \mathrm{mmol})$ in dry ether $(10 \mathrm{ml})$ over a period of $1 \mathrm{hr}$ to a cold solution of ethyl acetoacetate $(2.32 \mathrm{~g}, 20 \mathrm{mmol})$ in dry ether $(30 \mathrm{ml})$ with stirring. After complete addition, the reaction mixture was refluxed for $2 \mathrm{hr}$ on a water bath. The solvent was removed and the oil residue was then distilled under reduced pressure. The product was collected at $80^{\circ} \mathrm{C} / 200 \mathrm{mmHg}$ to afford $2.7 \mathrm{~g}$ $(85 \%$ yield $)\}$ in ethanol $(20 \mathrm{ml})$, sodium acetate trihydrate $(0.3 \mathrm{~g})$ was added. After stirring for $10 \mathrm{~min}$, the mixture was cooled to $0{ }^{\circ} \mathrm{C}$ and treated with the appropriate arene diazonium chloride solution [prepared by diazotizing the appropriate arylamine $(10 \mathrm{mmol})$ in hydrochloric acid (6 $M, 0.6 \mathrm{ml})$ with sodium nitrite solution $(0.07 \mathrm{~g}, 1 \mathrm{mmol})$ in water $(5 \mathrm{ml})$ ]. The addition of the diazonium salt was carried out with rapid stirring over a period of $30 \mathrm{~min}$. The reaction mixture was stirred for further $2 \mathrm{hr}$ at $0-5$ ${ }^{\circ} \mathrm{C}$, and then left for $6 \mathrm{hr}$ in a refrigerator. The resulting solid was collected by filtration, washed thoroughly with water and was then dried. The crude product was recrystallized from ethanol to give the corresponding hydrazonoyl chlorides (5a-b) [24]. 
Preparation of Aryl-2-bromoethanones (9)

To a stirred solution of acetophenone $(1.201 \mathrm{~g}$, $10 \mathrm{mmol})$ in dry ether $(20 \mathrm{ml})$, anhydrous aluminum chloride $(0.05 \mathrm{~g})$ was added. To the resulting mixture, bromine $(1.60 \mathrm{~g}, 10 \mathrm{mmol})$ was added dropwise over a period of $30 \mathrm{~min}$ with stirring. After complete addition, stirring was continued for further $20 \mathrm{~min}$. and the reaction mixture was poured onto cold water. The organic layer was separated, washed twice with water, then with sodium bicarbonate solution $(5 \%, 15$ $\mathrm{ml}$ ) and finally was dried over anhydrous sodium sulfate, then it was filtered. The solvent was removed under reduced pressure and the solid residue was recrystallized from ether to afford the corresponding compound 9 (lit. [25]).

\section{Organic synthesis and reactions \\ Preparation of Methyl hexadecanoate (Methyl palmitate) (1)}

Conc. sulfuric acid $(5 \mathrm{ml})$ was added to a mixture of hexadecanoic acid $(6.41 \mathrm{~g}, 25 \mathrm{mmol})$ and absolute methanol $(40 \mathrm{ml})$ in dry benzene $(100 \mathrm{ml})$, and heated under reflux for $6 \mathrm{hr}$ then it was cooled to room temperature, washed with water till complete removal of sulfuric acid. Then the ester layer was separated from benzene by extraction with diethyl ether, and the solvent was evaporated under reduced pressure [17]

Preparation of Hexadecanyl hydrazide (2)

To a mixture of methyl hexadecanoate (1) $(2.70 \mathrm{~g}, 10 \mathrm{mmol})$ in dry benzene $(30 \mathrm{ml})$ hydrazine hydrate $(0.49 \mathrm{ml}, 10 \mathrm{mmol})$ was added. The mixture was refluxed for $6 \mathrm{hr}$, then it was allowed to cool, and poured into acidified icecold water with continuous stirring. The formed precipitate was filtered off, washed with water, dried and recrystallized from ethanol [4].

Preparation of 1-Hexadecanoyl-4phenylthiosemicarbazide (4)

Acid hydrazide $2(2.70 \mathrm{~g}, 10 \mathrm{mmol})$ was dissolved in dry dioxane $(20 \mathrm{ml})$ and the phenyl isothiocyanate $(1.35 \mathrm{~g}, 10 \mathrm{mmol})$ was dissolved in absolute ethanol $(30 \mathrm{ml})$. The two mixtures were mixed together and heated under refluxed for $6 \mathrm{hr}$,then it was left to cool. The separated solid was then filtered off and recrystallized from appropriate dioxane [27].

Preparation of Ethyl-4-aryl-4,5-dihydro(5-hexaadecaneoylimino)-1,3,4-thiadiazole-2carboxylates (7a-b)

General procedure: A solution of thethiosemicarbazide $4(4.04 \mathrm{~g}, 10 \mathrm{mmol})$ in dimethylformamide $(20 \mathrm{ml})$, and triethylamine $(0.5$ $\mathrm{ml}$ ), was portion wisely added to the appropriate ethyl chloro(arylhydrazono) acetate (9) (10 mmol) with continuous stirring and over a period of $30 \mathrm{~min}$. After the addition was completed, the reaction mixture was stirred at room temperature overnight during which hydrazonoyl halide was dissolved and the product was precipitated. Then, the formed solid product was filtered off, washed with water, dried and recrystallized from ethanol and afford the corresponding thiadiazole derivatives [28] (7a-b).

Preparation of (5-Hexadecanyl)-2phenylamino-4H-1,3,4-thiadiazin-6-yl)(Aryl) methan- one (12)

To a stirred solution of the thiosemicarbazide $4(4.05 \mathrm{~g}, 10 \mathrm{mmol})$ in ethanol $(20 \mathrm{ml})$, The appropriate $\alpha$-haloketones $9(10 \mathrm{mmol})$ and triethylamine $(0.5 \mathrm{ml})$ were added, and the mixture was refluxed for $6 \mathrm{hr}$. The solvent was then evaporated under reduced pressure; As a result a white solid crystal appeared. The crude solid was then filltered and recrystallized from DMF[29] to afford the corresponding product (12).

The structures of all the synthesized compounds were confirmed according to their elemental analysis and spectral data (IR, $\mathrm{H}^{1} \mathrm{NMR}$, $\mathrm{C}^{13} \mathrm{NMR}$ and MS) as shown in Table 1.

\section{Antimicrobial activity}

The prepared compounds $(100 \mu \mathrm{g} / \mathrm{ml})$ were tested in vitro for antibacterial activity against four bacterial species (two gram positive and two gram negative) namely Staphylococcus Epiderm, Enterococus fesalis, Enterobacter cloacae, and Flavo-Bacterium, using disk diffusion method [30], for the antibacterial activity of each compound in diethyl ether as solvent.

Inhibition zone diameter (IZD), in $\mathrm{mm} / \mathrm{mg}$ compound was tested and taken as the criterion for antimicrobial activity.

The antibiotics Vacomycin - rifampin, Penicillin G, Gentamycin - cephpalosporin - cefotaxime Imipenem and Normal flora Natpathegen, were used as references to evaluate the potency of the tested compounds under the same condition.

\section{$\underline{\text { Results and Discussion }}$}

Physical and chemical properties of used oil

Refractive index which is primary indication for polymer formation and degree of conjugation

Egypt. J. Chem. 60, No. 4 (2017) 
which caused by broken the unsaturated center was found to be 1.457 at $25^{\circ} \mathrm{C}$ for the over used oil (Table 2).

On the other hand, the free fatty acid ( $\%$ as oleic acid) was found to be $1.03 \%$ which may be attributed to hydrolysis of triglyceride or oxidation of the unsaturated center.

Moreover the peroxide value of the over used oil was elevated to 13.42 meq. $\mathrm{O}_{2} / \mathrm{kg}$ oil. as a result of primary oxidation of the double bond.

Polymer content was rised to $6.02 \%$ by frying. and polar content was found to be $15.21 \%$ as a result of degradation of the fatty chain, and it is well known that the level of polar compounds is a good indicator of the overall quality of frying oils, providing critical information about the amount of newly formed compounds having higher polarity than triacylglycerols [31] and the oxidized fatty acids of the over used oil was found to be $4.33 \%$.

Fatty acid composition of over used oil

The over used oil fatty acids composition was confirmed qualitatively and quantitatively using Gas -liquid chromatography (GLC) as shown in Table 3 palmitic acid (C16:0) which is the first fatty acid produced during fatty acid synthesis and the precursor to longer fatty acids [32] was the major saturated fatty acid $40.73 \%$. Oleic acid (C18:1) which known by its responsibility for reduction of the low-density lipoprotein (LDL) cholesterol as well as the blood pressure [33] was represented to be the major monounsaturated fatty

\section{TABLE 1. Spectral and elemental analysis.}



Egypt. J. Chem. 60, No. 4 (2017) 
TABLE 2. Physical and chemical properties of the over used oil

\begin{tabular}{|c|c|}
\hline Parameters & $\begin{array}{c}\text { The Over Used } \\
\text { Cooking Oil }\end{array}$ \\
\hline Refractive index at $25^{\circ} \mathrm{C}$ & 1.457 \\
\hline Viscosity(cp) & 84.54 \\
\hline Free fatty acid (\%) & 1.03 \\
\hline Iodine value(gI/ $/ 100 \mathrm{~g}$ oil) & 43.36 \\
\hline $\begin{array}{c}\text { Peroxide value (meq. } / \\
\text { kg oil) }\end{array}$ & 13.42 \\
\hline polymer contents (\%) & 6.02 \\
\hline polar contents (\%) & 15.21 \\
\hline Oxidized fatty acids & 4.33 \\
\hline
\end{tabular}

TABLE 3. Fatty acid composition of over used cooking oil.

\begin{tabular}{|c|c|}
\hline $\begin{array}{c}\text { Fatty acids } \\
\text { composition (\%) }\end{array}$ & Values \\
\hline C12:0 & 0.55 \\
\hline $\mathrm{C} 14: 0$ & 1.54 \\
\hline $\mathrm{C} 16: 0$ & 40.73 \\
\hline $\mathrm{C} 16: 1$ & 0.32 \\
\hline $\mathrm{C} 18: 0$ & 4.71 \\
\hline $\mathrm{C} 18: 1$ & 42.86 \\
\hline $\mathrm{C} 18: 2$ & 8.26 \\
\hline $\mathrm{C} 18: 3$ & 0.11 \\
\hline $\mathrm{C} 20: 0$ & 0.32 \\
\hline Others & 0.19 \\
\hline Total saturated & 47.85 \\
\hline Total unsaturated & 51.74 \\
\hline
\end{tabular}

acid $42.86 \%$. linoleic acid (C18:2) which is the precursor for biosynthesis of arachidonic acid and consequently the prostaglandins, leukotrienes, and thromboxane [34] and which is much more susceptible to oxidation than mono unsaturated fatty acid, was shown to be $8.26 \%$.

Also, lauric acid (C12:0), myristic acid (C14:0), palmitoleic acid (C16:1), stearic acid (C18:0), linolenic acid (C18:3), arachidic acid (C20:0) and gobdoic acid (C20:1) were found in little amounts $0.55 \%, 1.45 \%, 0.32 \%, 4.71 \%$, $0.11 \%, 0.32$ and 0.19 , respectively. Moreover, the total saturated and unsaturated fatty acids were found to be $45.5 \%$ and $54.5 \%$, respectively.

\section{Reactions of methyl palmitate and its derivatives}

Methyl ester of palmitic acid (1) prepared by esterification of the corresponding long-chain fatty acid with methanol, was used as starting material,
Ester was then reacted with hydrazine hydrate in dry benzene furnished the corresponding hexadecanyl acid ydrazide (2).

The infrared spectrum of the hexadecanyl acid hydrazide (2) reveled strong absorption bands at $v$ $3334,3269-3197 \mathrm{~cm}^{-1}$ attributable to $\mathrm{NH}$ and $\mathrm{NH}_{2}$ groups. The carbonyl absorption in this compound was observed at $1652 \mathrm{~cm}^{-1}$. The mass spectrum of the same compound displayed a peak at $\mathrm{m} / \mathrm{z} 269$ $\left(\mathrm{M}^{+}\right)$which is identical to its molecular ion. Its ${ }^{1} \mathrm{H}$ NMR spectrum demonstrates the presence of signals due to $\mathrm{NH}$ at $\delta 8.20$ and at $\delta 2.29$ due to $\mathrm{NH}_{2}$, and aliphatic protons at $\delta 0.93-1.33$.

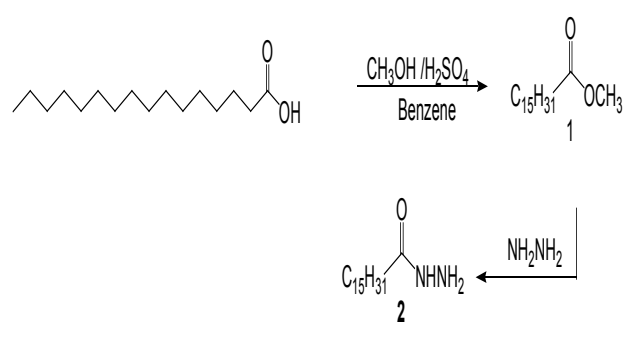

prepration of fatty acid hydrazide

The reaction of long chain fatty acid hydrazide 2 with phenyl isothiocyanate in dry dioxane, gave the compatible thiosemicarbazide (4), which was assured depending on its elemental analysis and spectral data, its IR spectrum exhibited a specific absorption band at $v 1662 \mathrm{~cm}^{-1}$ due to $\mathrm{C}=\mathrm{O}$ group, and other one at $1353 \mathrm{~cm}^{-1}$ that denote the presence of $\mathrm{C}=\mathrm{S}$ group. Also, its ${ }^{1} \mathrm{H}$ NMR spectrum displayed three $\mathrm{D}_{2} \mathrm{O}$-exchangeable signals at $\delta 7.97,2.32$ and 1.46 corresponding to three $\mathrm{NH}$ groups, and another multiplet signal at $\delta 7.20-7.64$ due to aromatic protons, and a multiplet at $\delta$ 0.94-1.32 corresponding to aliphatic protons. In the ${ }^{13} \mathrm{C}-\mathrm{NMR}$ spectrum of compound 4 , the signal of the carbon of $\mathrm{S}=\mathrm{C}$ was observed at $163.3 \mathrm{ppm}$, while the carbonyl carbon exhibit a signal at176.30 ppm, moreover the aromatic carbons were observed at $150.11,130.13,127.5$ and121.9176.30 ppm.

thiosemicarbazide (4) and ethyl chloro (arylhydrazono) acetate derivatives (5a-b) was reacted in dimethylformamide, and in the presence of triethylamine, afforded a single compound for which the two possible structures 7 and 8 can be expected. However, elemental analysis and spectral data were compatible

Egypt. J. Chem. 60, No. 4 (2017) 
only with the thiadiazole structure (7). Where the ${ }^{1} \mathrm{H}$ NMR spectrum of compound $7 \mathrm{a}$, taken as a typical example, detected a signals at $\delta$ 7.03 ( $\mathrm{D}_{2} \mathrm{O}$-exchangable) due to the $\mathrm{NH}$ proton, and other one at $\delta$ 7.1-7.3 corresponding to aromatic protons, in addition to signals at $\delta 0.92-$ 1.31 caused by aliphatic protons . On the other hand, its IR spectrum revealed a characteristic absorption band at $v 3371 \mathrm{~cm}^{-1}$ due to $\mathrm{NH}$, more over it exhibited two absorption bands at $v 1752$ $1670 \mathrm{~cm}^{-1}$ coressponding to two carbonyl groups. Also, its ${ }^{13} \mathrm{C}$-NMR spectrum showed signals of the aromatic carbons at 116.82, 124.22, 129.71 and144.50 ppm. For the ethyl group of ethyl carbonate derivatives, the $\mathrm{CH}_{3}$ and $\mathrm{CH}_{2}$ appeared in 13.77 and $60.71 \mathrm{ppm}$, respectively in addition to two carbonyl carbons signals at 160.98 and $175.30 \mathrm{ppm}$.

Production of compounds 7a-b was supposed to proceed via the alkylation of the thiosemicarbazide (4) to produce the acyclic non-isolable intermediates $(6 a-b)$ that underwent intramolecular cyclization through aniline molecule elimination to furnish the substituted thiadiazole derivatives $(7 a-b)$.
Reaction of thiosemicarbazide (4), in ethanol, with the haloketones 9 in the presence of triethylamine, was afforded in each case, only one isolated compound for which the two possible structures 11 and 12 could be established. However elemental analysis and spectral data were in agreement only with the thiadiazine derivatives (12). Where compound 12 revealed ${ }^{1} \mathrm{H}$ NMR signals at $\delta 8.81$ and 4.39 due to the two $\mathrm{NH}$ protons, moreover it exhibited a multiplate signal at $\delta$ 0.94-1.32 corresponding to an aliphatic protons. And its IR spectrum reveled two NH absorption bands at 3391 and $3310 \mathrm{~cm}^{-1}$, and other absorption band at $\vee 1653 \mathrm{~cm}^{-1}$ related to $\mathrm{C}=\mathrm{O}$ function. Moreover, ${ }^{13} \mathrm{C}$-NMR spectrum of this compound showed signals at 99.11, 154.85 and170.00 ppm due to three carbons in the thiadiazin ring, and other signal at $188.6 \mathrm{ppm}$ related to carbonyl carbon, in addition to aliphatic carbons at region 1402-31.9 ppm. The reaction smechanism of thiosemicarbazide (4) with haloketones was presumed to proceed via the non isolable acyclic intermediates 10 which underwent intramolecular cyclization via water molecule elimination to produce the corresponding thiadiazine (12).

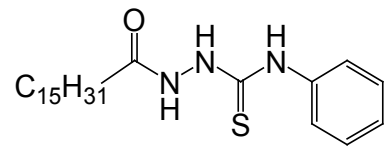

4<smiles>CCOC(=O)/C(Cl)=N/NBr</smiles>

$-\mathrm{HCl}$

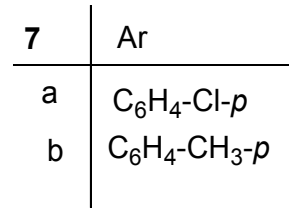

prepration of thidiazole derivatives 


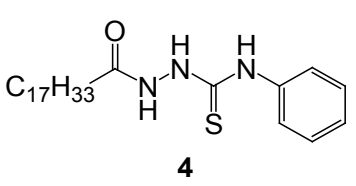

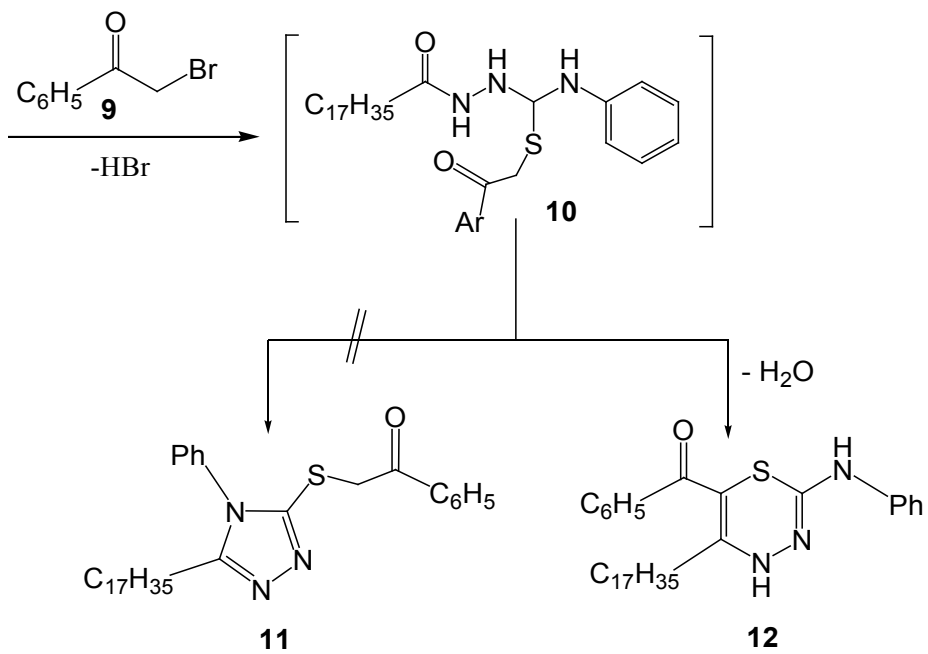

\section{prepration of thiadiazin derivative}

\section{Antimicrobial activity}

The results of antimicrobial activity are depicted in the following table, on the following basis:

- The solvent used was diethyl ether.

- Concentration of the sample in $100 \mu \mathrm{g} / \mathrm{ml}$.

- Inhibition zone diameter (IZD) $=2-10 \mathrm{~mm}$ beyond control $=+$ (low activity).
- Inhibition zone diameter (IZD) $=11-24 \mathrm{~mm}$ beyond control $=++$ (moderate activity).

- Inhibition zone diameter (IZD) $=25-35 \mathrm{~mm}$ beyond control $=+++$ (high activity).

By comparing the results from Table 4 to that obtained from pervious study [1], which was carried out on similar hetero cyclic compounds but those were attached to octadecanyl instead of hexadecanyl moiety and on the same bacterial

TABLE 4. Antimicrobial Activity of the Tested Compounds.

\begin{tabular}{|c|c|c|c|c|}
\hline \multirow{3}{*}{$\begin{array}{l}\text { Compound } \\
\text { No. }\end{array}$} & \multicolumn{4}{|c|}{$\begin{array}{l}\text { INHIBITION ZONE DIAMETER (IZD) } \\
\text { (MM/MG COMPOUND TESTED) }\end{array}$} \\
\hline & \multicolumn{2}{|c|}{ Gram + ve } & \multicolumn{2}{|c|}{ Gram - ve } \\
\hline & $\begin{array}{l}\text { Staphylococcus } \\
\text { Epiderm }\end{array}$ & $\begin{array}{l}\text { Enterococus } \\
\quad \text { fesalis }\end{array}$ & Enterobacter. cloacae & Flavobacterium \\
\hline Control & 0.0 & 0.0 & 0.0 & 0.0 \\
\hline 4 & $+\mathrm{ve}$ & $+\mathrm{ve}$ & ++ ve & $++\mathrm{ve}$ \\
\hline $13 a$ & ++ ve & ++ ve & ++ ve & ++ ve \\
\hline $13 b$ & ++ ve & $+\mathrm{ve}$ & ------- & ++ ve \\
\hline $20 \mathrm{a}$ & -------- & ++ ve & + ve & $+\mathrm{ve}$ \\
\hline $20 \mathrm{~b}$ & ++ ve & ++ ve & +++ ve & ++ ve \\
\hline $20 \mathrm{c}$ & ++ ve & ------- & ++ ve & ------- \\
\hline References & $\begin{array}{l}\text { Vacomycin - } \\
\text { rifampin }\end{array}$ & Penicillin G & $\begin{array}{c}\text { Gentamycin - } \\
\text { cephpalosporin - } \\
\text { cefotaxime Imipenem }\end{array}$ & $\begin{array}{l}\text { Normal flora } \\
\text { Natpathegen }\end{array}$ \\
\hline
\end{tabular}


species, it was found that, antimicrobial activity of the newly prepared compounds did not show significant difference from that of octadecanyl moiety. Thus, the small difference in the length of fatty moiety does not affect the antimicrobial activity of the compound.

\section{Conclusion}

The new prepared compounds are expected to be biologically beneficial in combating microorganisms, moreover these compounds are expected to have several advantages over the parent heterocyclic one, where they may easily penetrate the lipoprotein cell membrane, they may be stored in liver and skin as a lipid component that can be used whenever they needed, also the toxicity and side effects of this new compounds may be reduced by the presence of the long chain fatty acid residue which circulate the hetero nucleus [17].

\section{References}

1. Alexander F. Pozharskii, Anatoly T. Soldatenkov and Alan R. Katritzky, Heterocycles in Industry and Technology, Heterocycles in Life and Society: An Introduction to Heterocyclic Chemistry, Biochemistry and Applications, Second Edition Published Online: 31, MAR 2011

2. Mukhtyar, S. Saini, Aran Kumar, Jaya Dwivedi and Rakesh Singh, A review: biological significances of heterocyclic compounds. International Journal of Pharma Sciences and Research, 4 (3), 66-78, (2013).

3. El-Etrawy, A. Sh. and Abdel-Rahman, A. A.-H., Synthesis and antiviral evaluation of 1,3-dimethyl6-(1h-1,2,3-triazol-1-yl)pyrimidine-2,4(1h,3h)dione derivatives. Chemistry of Heterocyclic Compounds, 46 ( 9), 1105-1108, (2010).

4. Palaska, E., Sahin, G., Kelicen, P., Durlu, N.T. and Altinok, G., Synthesis and anti-inflammatory activity of 1-acylthiosemicarbazides, 1,3,4-oxadiazoles, 1,3,4-thiadiazoles and 1,2,4-triazole-3-thiones, Farmaco. 57, 101-107 (2002).

5. Onkol, T., Cakir, B. and Sahin, M.F. Şahin, Synthesis and antinociceptive activity of 2-[(2-oxobenzothiazoline-3-yl)methyl]-5-amino alkyl/aryl-1,3,4-thiadiazole, Turk. J. Chem. 28, 461-468 (2004).

6. Schenone, S., Bruno, O., Banise, A., Bondavalli, F.,Filippeli, W., Falcone, G., Giardano, L. and Vitelli, M.R., Bioorg. Med. Chem. 9, 2149-2153

Egypt. J. Chem. 60, No. 4 (2017)
(2001)

7. Gokce, M., Cakir, B., Erol, K. and Sahin, M.F., Synthesis and antinociceptive activity of [(2-oxobenzothiazolin-3-yl)methyl]-4-alkyl/aryl1,2,4-triazoline-5-thiones, Arch. Pharm. 334, 279283 (2001)

8. Baldwin, J.J., Engelhardt, E.L., Hirschmann, R., Ponticella, G.S., Atkinson, J.G., Wasson, B.K., Sweet, C.S. and Scriabini, A. Scriabini, Heterocyclic analogues of the antihypertensive beta-adrenergic blocking agent (S)-2-[3-(terbutylamino)-2-hydroxypropoxy]-3-cyanopyridine, J. Med. Chem. 23, 65-70 (1980)

9. Varvaresou, A., Tsantili-Kakoulidou, A., SiatraPapastasikoudi, T. and Tiligada, E., Synthesis and biological evaluation of indole containing derivatives of thiosemicarbazide and their cyclic 1,2,4-triazole and 1,3,4-thiadiazole analogs, Arzneimittelforschung, 50, 48-54 (2000).

10. Foroumadi, A., Mirzaei, M. and Shafiee,A., Synthesis and antituberculosis activity of 2-aryl1,3,4-thiadiazole derivatives, Pharmazie, 56, 610612 (2001).

11. Mamola, M. G., Falagiani, V., Zanpieir, D., Vio, L. and Banfi, F., Synthesis and antimycobacterial activity of [5-(pyridin-2-yl)-1,3,4-thiadiazol-2ylthio] acetic acid arylidene-hydrazide derivatives, Farmaco, 56, 587-592 (2001).

12. Chen, H., Li, Z. and Han, Y., Synthesis and fungicidal activity against Rhizoctonia solani of 2-alkyl (Alkylthio)-5-pyrazolyl-1,3,4-oxadiazoles (Thiadiazoles), J. Agric. Food Chem. 48, 53125315 (2000).

13. Zou, X.J., Jin, G.Y. and Zang, Z.X., Synthesis, fungicidal activity, and QSAR of pyridazinonethiadiazoles, J. Agric. Food Chem. 50, 1451-1454 (2002).

14. Zou, X.J., Lai, L.H., Jin, G.Y. and Zhang, Z.K., Synthesis, fungicidal activity, and 3D-QSAR of pyridazinone-substituted 1,3,4-oxadiazoles and 1,3,4-thiadiazoles, J. Agric. Food Chem. 50, 37573760 (2002).

15. Dong, X.G., Yan, L., Song, X.J. and Du, Y.X., Synthesis and antimicrobial activity of $\mathrm{N}$-[ 5-(3-pyridyl)-1, 3, 4-thiadiazol-2-yl] -N'-aroyl urea, Yao Хие Хие Bao. 42, 108-110 (2007).

16. Clerici, F., Pocav, D., Guido, M., Lochi, A., Perline, V. and Brufani, M., Synthesis of 2-amino5-sulfanyl-1,3,4-thiadiazole derivatives and 
evaluation of their antidepressant and anxiolytic activity, J. Med. Chem. 44, 931-936 (2000).

17. Soliman, Hanaa Mohamad etal., Utilization of Stearic acid extracted from olive pomace for production of Triazoles, Thiadiazoles and Thiadiazines derivatives of potential biological activities J. Oleo Sci., 64, No.9 (2015)

18. Soliman, H.M., Synthesis of some fat based heterocyclic from olive oil production waste precursors. Ph.D. Thesis, Chemistry Department College of Sciences, Cairo University (2010).

19. A.O.A.C. (Association of Official Agriculture Chemists) Official Methods of Analysis of $18^{\text {th }}$ ed., D.C. USA (2005).

20. Wu, P. F. and Nawar, W. W., A technique for monitoring his quality of used frying oils. Journal of the American Oil Chemists Society, 63, 13631367 (1986).

21. Waltking, A. E. and Wessels, H., Chromatographic separation of polar and non-polar components of frying oils. Journal of the Association of Official Analytical Chemistry, 64, 1329-1330 (1981).

22. Sonntag, N.O.V., Johnson, R.W. and Fritz, E., Fatty Acids in Industry. Marcel Dekker, Inc., New York, pp. 23-72 (1988)

23. Maheshwari, P., Nikolov, Z.L., White, T.M., Hartel, R., Solubility of fatty acids in Supercritical carbon dioxide. J. Am. Oil Chem. Soc. 69, 1069-1076 (1992)

24. Hegarty, A.F., Cashman, M.P. and Scoit, F.L., Title Chem. Commun. 13, 884- (1971).

25. Cowper, R.M. and Daviadson, L.H., PHENACYLBROMIDE[Acetophenone, $\alpha$-bromo-] Organic Synthesis Coll. 2, 480-481 (1943).

26. Rauf, A., Sharma, S. and Gangal, S., Microwave assisted efficient one-pot synthesis of 3,5,6-trisubstituted-1,2,4-triazines from fatty acid hydrazides under solvent-free conditions and their antimicrobial activity. ARKIVOC xvi, 137-147 (2007).

27. Abdelmadjid Benmohammed et al., Synthesis of novel highly functionalized 4-thiazolidinone derivatives from 4-phenyl-3-thiosemicarbazones. Molecules, 19, 3068-3083 (2014).

28. Abdelriheem, Nadia A., Mohamed, A. M. M. and Abdelhamid, A. O., Synthesis of some new 1,3,4-thiadiazole, thiazole and Pyridine derivatives containing 1,2,3-triazole moiety. Molecules, 22, $268(2017)$

29. Milan Čačić et al., Design and synthesis of some new 1,3,4-thiadiazines with coumarin moieties and their antioxidative and antifungal activity. Molecules, 19, 1163-1177(2014).

30. Gould, J. and Bowie, J.H., The determination of bacterial sensitivity to antibiotics. Edinb. Med. J. 59, 178-199 (1952).

31. Blumenthal, M. M., A new look at the chemistry and physics of deep-fat frying. Food Techn. 45, 6894 (1991)

32. Kingsbury, K. J., Paul, S., Crossley, A. and Morgan, D. M., The fatty acid composition of human depot fat. Biochemical Journal. 78, 541-550 (1961).

33. Teres, S., Barcelo-Coblijn, G., Benet, M., Alvarez, R., Bressani, R., Halver, J. E., Escriba, P. V., Oleic acid content is responsible for the reduction in blood pressure induced by olive oil. Proceedings of the National Academy of Sciences. 105 (37),138116 (2008).

34. Funk, Colin D. Prostaglandins and Leukotrienes,Advances in Eicosanoid Biology. Science, 294 (5548), 1871-1875 (2001).

(Received:19/3/2017; accepted: $24 / 4 / 2017$ ) 


\section{فصل حامض البالمتيك من الزيوت المستهلكة لإنتاج مشتقات عضوية غيرمتجانسة ذات نثاط بيولوجي محتمل \\ هناء محمد سليمان ويوسف علي الثناطوري المركز القومي للبحوث ـ الجيزة ـ مصر الفران}

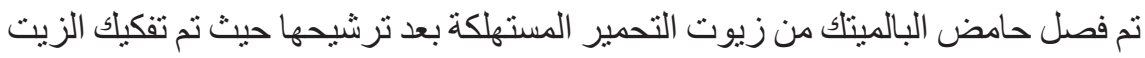
إلى احماض دهنية و جلسرول بإستحدام المياه المقطرة عند درجة حرة الإنة

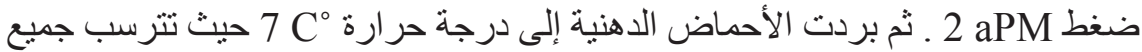

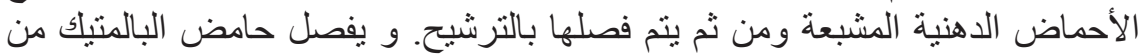

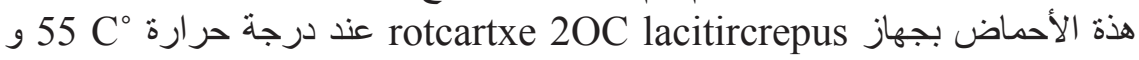

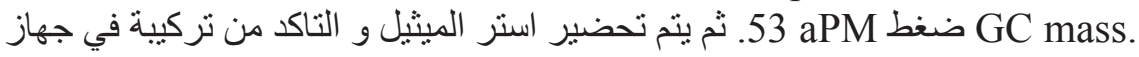

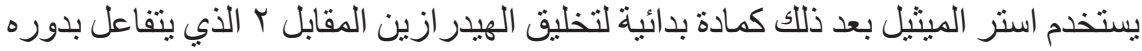

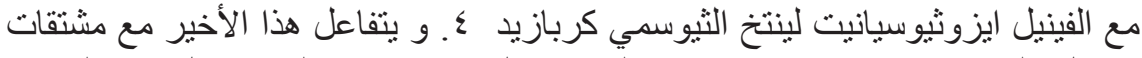

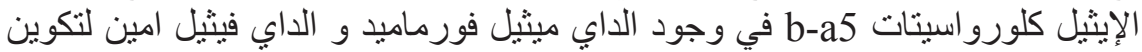

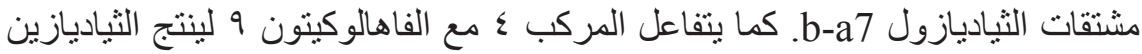

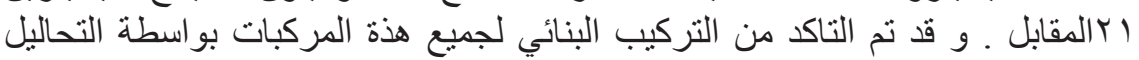

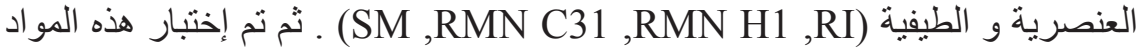
كمضادات لبعض انواع البكتريا. 